\title{
The Development of Inheritance Customary Law For The Heirs of Girls According To The Patrilineal Kinship System
}

\author{
Afnaini \\ Nasional University, Indonesia \\ Email: afnainieni@gmail.com
}

\begin{abstract}
:
Inheritance law in Indonesia is still plural, this happens because Indonesia does not yet have a National Inheritance Law that applies to all Indonesian people. In connection with the absence of the law, in Indonesia there are still three (3) kinship systems, i.e. the kinship system, the parental kinship system and the matrilineal kinship system. Additionally, through the Decree of the Supreme Court of the Republic of Indonesia dated November 1, 1961 Reg No. 179/K/Sip/1961 which states that the girl and boy of a joint heir are entitled to inheritance in the sense that the share of boys is equal to that of girls. The problems in this research are 1) how to development of inheritance distribution practices for inheritance to girls in the patrilineal kinship system 2) how is the direction of development of customary inheritance law towards inheritance to girls in the patrilineal kinship system? This study uses research methods with a normative approach. The results showed that the practice of dividing inheritance for inheritance to girls in the patrilineal kinship system has undergone changes in several factors that effect the development of changes in indigenous peoples, including education, overseas/migration, economic and religious factors as well as social court decisions. 2) The direction of development of customary inheritance law towards inheritance to girls in the patrilineal kinship system began with the issuance of Supreme Court Decision Number 179K/Sip/1961 and has moved towards a patrilineal system that provides equality towards equality and rights for boys and girls because it is influenced by human factors, justice and equality between men and women.
\end{abstract}

Keywords:

inheritance; girls; patrilineal

\section{Introduction}

Indonesia accepts the existence of customary law which is part of the life and culture of customary peoples' law, as contained in the Constitution of the Republic of Indonesia 1945 (UUD 1945) in paragraph (2) Article 18 B and paragraph (3) Article 28 I of the definition of the two Articles above, then out Law No. 39 of 1999 on Human Rights (Human Rights Law) which contains arrangements for respect for indigenous peoples, In Article 6 paragraph (1) it is mentioned "in the framework of the enforcement of human rights, the differences and needs of indigenous peoples must be considered and protected by the laws of the community and the government." .

Customary law is part of culture of the region as a nation wealth that needs special attention, especially when talking about preservation and introduction to children. Introducing culture to the younger generation, especially children, is carried out in various ways. Customary law as a rule of human habits in community life that existed since the presence of humans on earth then he lived his life as part of the family, society, and state. If you look at the development of living humans, then the law begins with the human person who is given reason and behavior. 
Customary law as a law that lives in the existing community (living law) and grows and develops in the community as its development in society in general. Customary law that is in the midst of Indonesian tribal life becomes very important to know so that the protectors, law enforcement and legal observers to apply appropriate and fair laws for the people of Indonesia.

Customary law in general has not been or is not written, Habit is a term commonly used in the life of society customary, terms that also have differences and similarities and with customs where customary law includes regulations made by the people and for the people themselves. With the sanctions given by the customary chairman for the rules violated. Customary law in the Indonesian nation stems from the existing unwritten legal regulations developed and maintained with the legal awareness of indigenous peoples. Because the regulation is not written and grows, the customary law can be accommodated and adjusted. In addition, it is also known as a group of people who are bound by the customary legal order which is a part of citizen with a legal alliance due to the similarity of residence or on the basis of heredity.

The law of inheritance deals with the scope of human life. Every human being will experience a very important event in his life that becomes a legal event that is passing away. According to Wirjono, "inheritance is a matter of what and how the division of rights and obligations about a person's wealth at the time of death turns to others who are still alive." . If a legal event is found, such as the death of someone that results in the loss of family members at once will result in the law, namely what is the continuation and how to take care of the deceased person. It deals with inheritance law by resolving and taking care of the rights and legal consequences of a legal event due to a person who died.

According to Prodjojo, saying "the notion of heirs has three (3) absolute (essential) relationships that are interrelated, such as:

1. A person who died and left his wealth.

2. Heir who is entitled to the wealth that has been left behind.

3. Inheritance, in the form of "in concreto" wealth left by the heir and once transferred to the heirs".

In Indonesia the existence of inheritance law is still pluralistic, because it imposes three (3) inheritance legal systems, such as inheritance law in the Civil Law Code, inheritance law in Islam, and customary inheritance law. Special inheritance law customarily consists of norms, principles, and provisions of the law related to the forwarding and control of property and property acquired from its heredity (nasab) line and its arrangements and transitions. The transition starts from the owner (heir) of the property still exists and runs sustainably so that it has offspring who become part of a new family that can be independent.

Based on customary law the division of inheritance can be carried out after the heir dies but when living the division of inheritance can be made. There is equality for both men and women due to the role of government. This is very much related to the perspective that men have a greater responsibility in a family, while girls are responsible to the family after marriage which changes by entering the husband's family environment and fulfilling his responsibilities.

The kinship system that exists in the community has characteristics that have differences and have their own patterns according to their indigenous peoples. According to customary law inheritance can be divided for generations before the heir dies, this is based on the results of family deliberations. With the diversity of the customary law inheritance system, it will also 
have different consequences, for that inheritance law must adjust based on its customs and culture with the shortcomings and advantages of the inherition system embraced.

In general, there are several kinship systems owned by Indonesia, at least, there are three (3) kinds of systems in kinship, i.e. the matrilineal kinship system, patrilineal kinship system and parental/bilateral kinship system, Each explanation of the kinship system is as follows:

1. Parental Kinship System, According to Suparman "this system is often known as the bilateral kinship system which is a kinship system that draws bloodlines from the father's lineage and maternal lineage, thus the kinship system system like this is no difference on the part of both the mother and father". When a person becomes a descendant in a family relationship because of the marriage carried out by Father and Mother then the system used is the parental system.

2. Patrilineal Kinship System is an interesting kinship system based on its lineage based on one of the parties, viz. the father. Thus the child is connected to his father, according to the male lineage. In addition, this kinship system can also connect between children with relatives of the father according to unilateral lineages (male lineages).

3. Matrilineal Kinship System is the opposite of patrilineal kinship system which is a system that has kinship based on maternal lineage upwards and so on from female ancestors making the maternal line get a higher degree than men.

According to Hilman the patrilineal system, also known as honest marriage, is "a form of marriage with the payment of money from male relatives to female relatives aimed at incorporating women into her husband's clan. So that the children who are born get the next generation of father. Therefore, patrilineal societies that draw lineages based on the father line make the position of men more influential than the degree of women in inheritance law".

Men in the patrilineal kinship system have higher degrees. This gives rise to discrimination against gender equality hidden in indigenous law societies. The boy is the heir, is the successor of the family, the successor of the descendants, is part of the indigenous community that plays a role in taking family decisions widely. The ways of division by calculation are not known in customary law, this is based on consideration of tangible objects and the needs and desires of heirs who have relationships. This phenomenon makes girls number two and get less attention. With the introduction above, this interesting research was conducted in the form of a journal with the title of Development of Inheritance Customary Law for Girls Heirs According to the Patrilineal Kinship System.

\section{Review of Literature}

\subsection{Understanding of Inheritance Customary Law}

Titik says "inheritance law according to customary law is a set of rules that govern the succession process from generation to generation. It is further said that customary inheritance is a set of rules for heirs to regulate the transfer of tangible property and intangible property from one generation to the next." . Customary inheritance law is a law that regulates the inheritance or division of an inheritance from heirs to subsequent heirs and from generation to next generation. The term inheritance is Arabic absorbed into the Indonesian. The customary law of inheritance is not only related to inheritance but also with its heirs even more broadly.

According to Hilman "customary inheritance law is a rule of law to regulate how the process of forwarding and transitioning wealth both tangible and intangible from the current generation to future generations". Hilman Subsequently said "Customary inheritance law is customary law that governs the provisions of the system, the principles of inheritance and 
inheritance law, whose ownership and ownership are transferred to the heirs. The customary law of inheritance actually contains the law about bequeathing property from one generation to its descendants." . According to Ter Haar "Customary inheritance laws are the rule of law on how from century to century the transfer and transfer of tangible and intangible property from generation to generation". According to Soepomo, "Customary inheritance law contains regulations governing the process of inheritance and inheritance of property and intangibles from a generation of humans to their descendants.".

\subsection{Inherited System in Customary Law}

In Indonesia, the division of inheritance regulated according to customary law cannot be equalized. Especially in the inheritance system based on the kinship system that applies to indigenous peoples. In general, the prevailing kinship system includes matrilineal, parental and patrilineal kinship systems. In addition, customary inheritance is also based on the inheritance system that applies to every indigenous law society. At least in Indonesia knows three (3) inheritance systems, i.e. the majorat inheritance system, the individual inheritance system and the collective inheritance system. In some indigenous peoples there are those who apply a mixed system that combines several systems of inheritance of customary law.

\section{a. Collective System}

The collective system is usually applied to bilateral/parental kinship communities. In the collective system arranged the division of inheritance by placing each male and female heir in obtaining a share by mastering and having an inheritance based on their respective parts. The uncharacteristic of the collective inheritance system is the inheritance inherited and managed by a group of heirs in inseparable conditions, as if to be a family law entity (ordinary legal entity). If heirs receive the inheritance they receive collectively from the indistinguishable heirs one by one, then such a legacy constitutes a collective inheritance. In this inheritance system, heirs do not personally own inherited property, but they are allowed to wear, present and get benefit. In general, this collective inheritance system applies to inheritance in the form of land (agriculture) and/or inheritance.

\section{b. Majorate System}

The characteristic of the majorate system is the inheritance of parents or ancestral property so that relatives remain intact and not divided among the heirs, but in the mastery of the oldest boys (majority of men) But in patrilineal communities in Lampung and Bali, still controlled by the oldest girls (majority of women) this happens in the matrilineal community of Semendo in South Sumatra and Lampung Region. According to Nalle "in its implementation this majorate system is not much different from the system of collective inheritance. The transfer of control over inheritance can be delegated to the firstborn who has a role as a substitute for heirs in a family. The majorate system can be affected by the kinship system applied i.e., between the patrilineal and matrilineal systems.".

In the coastal population of Lampung some indigenous people adhere to the male majorat inherition system. The system of collective inheritance is different from the system of inheritance of indigenous peoples, but as a successor and transfer of the right of ownership of the property that is not divided into the authority of the eldest child who acts as a household leader and serves as the head of the family replacing the role of father or mother as the head of the family. He gave control of all the property to the eldest son, according to the indigenous people on the coast of Lampung. It means being a responsible successor after the parents die, in order to have responsibility for the relics and responsibility for the lives of their immature siblings, so that they can stand on their own. 
According to Hilman "the son of punyimbang as the oldest son of the oldest wife, in Lampung District acts as a leader, organizes and manages the right of ownership of relics." Additionally, Hilman said "the goodness and weaknesses of the majorat inheritance system, can be seen from the leadership carried out by the oldest child who has a position as a substitute for his parents who have died, in managing wealth and benefiting the benefit of all family members who have been abandoned, because this is because the oldest child is not as an individual owner of relics, but as a mandate holder of parents who are limited by deliberation in the family, which is limited by the obligation to take care of parents who are limited by other family deliberations, and based on mutual help".

\section{c. Individual Inherition System}

The individual inheritance system has the characteristics of relics that are divided into ownership for heirs, as there is applicable according to the Civil Law Code, and Islamic Law, as well as those that apply in indigenous communities such as those of families in Java who adhere to the parental inheritance system, this also happens to families in Lampung who adhere to patrilineal. Usually this system occurs and applies among independent family communities, which do not have a strong attachment to kinship relationships.

\subsection{Various Inheritance}

The meaning of inheritance is the legacy of someone who has died to the heirs. Relics inherited in customary law are inheritances that can be in the form of property or not shaped like a noble title. Inheritance in the form of property according to customary inheritance law is a means of livelihood, in the form of property received before marriage and inheritance.

\subsection{Position of Children on Customary Inheritance}

Relationship and position of the child to his parents will cause rights and obligations that have a reciprocal relationship for parents towards their children, this is in accordance with the structure of kinship embraced, the system of blood ties, the form of marriage carried out and also the form of marriage between father and mother, including the habits and relationships that occur between parents and children. In the patrilineal kinship system, the kinship system takes precedence over patriarchal kinship and in the usual customary marriage applies to pay fair money, provided that after marriage, the wife joins into her husband's kinship.

In general, boys and girls are heirs, including children in the womb if born alive, but not all children become heirs of parents who die because there are children who cannot be made heirs. Patriarchal indigenous peoples prefer the position of boys over girls, boys are the successors of their father's descendants who are descended from one father, and girls willingly become the children of others, which will strengthen the offspring of others. In general, according to the provisions of the law and customary law, the determination of whether or not a child is valid is related to legal reality, not biological. Under the reality of non-biological law it is understood that if a child is born to a father and mother in a valid marriage, then the child is legal.

\section{Research Methods}

According to Marzuki, "legal research is a process for finding the rule of law, legal principles, and legal doctrines to answer the legal issues faced by the law." . According to Ali, "the approach method in writing this research is a normative approach. Normative approach is one of the methods of legal research by conducting literature research that follows the legal norms contained in the provisions of legislation and court decisions and legal norms that apply in society." . 
According to Soerjowinoto "the research specifications used are descriptive analytical. Descriptive analytical is describing legal conditions that occur in the field, decriptive used by researchers to describe legal symptoms, characteristics of legal symptoms and the frequency of the presence between legal symptoms or legal events with each other." .

Soerjowinoto further said "the procedure of collecting legal materials used in this study is a literature study of legal materials, literature studies are methods used to obtain secondary data related to research objects, obtained through primary legal materials, secondary legal materials and tertiary legal materials." . The search for research materials focuses on primary legal materials, both in the form of relevant legislation used in looking at changes in customary inheritance law to girls as heirs in the form of patrilineal kinship. In addition, secondary legal materials and tertiary legal materials are used in the form of materials, available concepts contained in textbooks, with the aim of improving the status of indigenous peoples in the provisions of law in Indonesia.

Writer uses a research method with qualitative analysis that contains an analysis based on the picture of the analyzed data and the benefits obtained from the data which is further used to solve the problem. . With the data, it is arranged properly and systematically which is then carried out analysis using qualitative data analysis methods.

\section{Result and Discussion}

\subsection{Development of Inheritance and Division of Girl's Inheritance According to Patrilineal Kinship System}

The customary law of inheritance is the local law of an area that is believed and carried out on the people in the area. This law is influenced by various kinship relationships and the structure of indigenous peoples that it has. In Indonesia, customary inheritance law is closely related to the principle based on existing lineages and applied in the community. According to Dewi "heritage is a property that will be passed on by the heir when he is alive or dead, to be controlled or owned by heirs based on the system of kinship and inheritance that applies in the indigenous peoples concerned.".

Customary law is a part of customary law that remains in force with a kinship system that follows patrilineal lineages by distinguishing the position between girls and boys. In the patrilineal kinship system the offspring (boys) of men are made the generation that replaces the position of the father, but this is different from girls, because for girls his position in the family is only temporary, because the girl will in time marry, and follow the husband, and enter as a group of her husband. As long as her daughter has not married, she will be part of her father.

A daughter is not the heir of her father in a society that adheres to a patrinial system this is different for boys who are heirs. In his place, the girl gets a gift. But based on the Supreme Court (MA) decision dated July 31, 1973 Number 1037K / Sip / 1971. MA stated that "girls are also heirs and have the right to ownership of abandoned inheritance".

Principles applied in the patrilineal system and the principle of inequality can effect the change in the position of girls. But with the enactment of Tap MPRS No. II/1960 which was followed by the issuance of Mahkamah Agung No. 179K/Sip/1960 and MA Decree No. 179 $\mathrm{K} / \mathrm{Sip} / 1961$ and until the issuance of Law No. 1 of 1974 on Marriage Law as a result of the impact of science, economics and politics made the position that girls had in relation to inheritance, especially in Batak people has changed. 
MPRS Decree No. 11/1960 in letter c contains, that for all property for children and widows when leaving property and children and widows. MA in its ruling 179K/SIP/1961 in terms of inheritance aligns rights for boys, girls and widows. Additionally, according to Article 35 of Law No. I of 1974 it is stated that:

a. Treasures acquired during the marriage become joint treasures.

b. Treasures obtained by each of them are gifts or inheritances are under their own control."

Thanks to these changes it became clear that there has been equality in the rights of both men and women, both the principles of justice and equality, the humanity principles. The effect of increasingly rational people's thinking leads to better changes in customary law that occur as a result of various things. At first this was considered foreign to customary law, and until the issuance of MPRS Decree No. 11 of 1960 and Decree no. 179K / SIP / 1961 must follow the current system in customary law, known as the kinship / paternity system. A system in the family that makes the position of women in households and indigenous peoples stronger.

There are five (5) factors that can affect the development of customary inheritance law, i.e. jurisprudence, education, migration, economic, social, religion and jurisprudence.

1. Education

Education has an effect on the development of inheritance law. This can be seen from the high education of someone who changes the way of thinking that is growing and can follow the development of the surrounding environment. Education will change a person from initially accepting what he is to a more critical figure to undergoing changes that can benefit himself, his environment and his community to interact with one another. Effect in inheritance customs, which was once only boys who were entitled to inheritance in the patrilineal system, because with education then the way of thinking uses with logic, then one is more likely to choose the fair in terms of the division of inheritance.. So that the inheritance to boys and girls is divided equally.

\section{Migration}

Migration is the transfer of the population of one area to another in order to find their lives in order to live decently and better than before, in the intended overseas area. The migration is not only in order to make a living for migration actors but also affects the customs or the legal habits of heirs from their home regions that previously adhered to patrilineal to adhere to parental inheritance customary laws that apply in their place of residence.

\section{Economics}

The economic aspect of every human being is influenced by his family life. Including the need for living expenses and increasingly expensive education costs. In addition, what must be considered is the cost of living after the husband (father) died. It is the most important thing to ensure the life and future of children who have been born from a marriage. Based on customary provisions influenced by the patrilineal system and the condition of society in Indonesia, which generally male parents have the responsibility to provide a living to their families, because men work. Sometimes found wive or mother who work, this happens to be nothing but to support the economic life of his family.

\section{Social}

The customary customs that indigenous peoples have in marriage still survive. In a marriage to give honest money is still done and becomes a habit that is still maintained it is very important for indigenous peoples to show one's social status to the woman to be married. 
4. Religion

In Indonesia religious factors greatly influence the development and change in inheritance, because religion regulates inheritance.

5. Jurisprudence.

Article 1 of Law No. 14 of 1970 on the Basic Provisions of Judicial Power says: "Judicial power is the power of an independent state to hold a judiciary to uphold law and justice based on Pancasila, for the sake of the implementation of the State of Law of the Republic of Indonesia". Under Article 27 of Law No. 14/1970, it states that "judges authorized for law enforcement and justice shall examine, follow and understand the values of living law, in society". Thus it is known that, in society still know the law is not written and is in a time of upheaval and transition.

A judge is a framer as well as a examiner for the legal values that live in society. Therefore, a judge must be in the midst of society to feel, know, and to dive into the feelings of law and the sense of justice that lives in people's lives. So that the judge, able to impose a verdict that can be accepted as the provisions of the law and a sense of justice for the community.

Jurisprudence as a legal development related to social change is the Supreme Court's Decision of October 23, 1961 No. 179 K/Sip/1961 which reads: "The Supreme Court considers the law that lives throughout Indonesia, as well as in the Land of Batak Karo that the girls and boys of an heir are jointly entitled to inheritance, in the sense that the part of boys is the same as girls".

In the future the benefits of the existence of jurisprudence, namely if there is a inheritance dispute, on the party who feels aggrieved, especially losses against women, then the female party can file a claim for inheritance dispute to the district court, and to resolve the law the judge can argue on jurisprudence, which is about the provisions in the division of equal inheritance rights to both boys and girls.

Structure of society is very influential on the inheritance system. For example, in the patrilineal structure of society, the society structure that attracts the lineage of men as parties who are entitled to continue the lineage is a boy (male offspring) while for a married girl will leave the patrilineal kinship of her family and will further enter the structure of her husband's society, i.e. patrilineal.

The view of justice will never be the same at a different place and time. The sense of justice is taken following the feelings of society and becomes the rule of law. For people who have a simple life, the law is also simple, and vice-versa for modern society the laws that govern society are already complex. Another problem that needs to be considered to experience change is the understanding of the family past and present, thus giving influence to the provisions that speak about inheritance, marriage and marital objects, but often changes and shifts along with developments that occur in the midst of society.

The change in the position of girls and widows is a development of the position of women and widows in terms of inheritance, occurred at the time of Enactment of Tap MPRS Number II of 1960, namely regarding the Construction of National Law in Annex A Article 402 called:

a. There is an effort towards homogeniteite legal unity in an effort where it must be considered living reality. 
b. Principle of national law development is adapted to the direction of the state and based on customary law that does not hinder the development of a just and prosperous society.

c. All property is for children and widows when the property is left behind children and widows."

The existence of customary law can be used as part of the law that becomes the basis and reference in terms of dividing inheritance. The position of children in the division of inheritance is an important thing that is directly the cause of the inheritance process from parents to their children.

In the patrilineal inheritance system, boys are entitled to inherit. But with this system of inheritance sharing, if a daughter becomes the heir, then the property received by the man belongs to his brother, and the female side gets only a little. Now it is appropriate for the division of inheritance to follow the changes that usually occur in the division of inheritances both men and women. So it's not just men who inherit, because today the role of women in society is so broad, and there is equality between men and women. The girls position is formed in accordance with equal rights in bequeathing the inheritance of parents with boys who are considered equal in inheritance. Thus, patrilineal community system, especially among indigenous peoples, has developed in the direction of the Parental /Bilateral system.

\subsection{Direction of Development of Inheritance Customary Law for The Heir of Inner Daughters According to Patrilineal Kinship}

According to inheritance law, a woman is entitled to the inheritance of her parents. But because it is influenced by the kinship system that implements the patrilineal system, boys' rights are prioritized over girls' rights. Therefore, a girl can only wait until she is given a share based on the tolerance given from her parents or brother.

There are three (3) systems of customary law inherition known in Indonesia, i.e. majorat, individual and collective. In the majorat inheritance system, the eldest child controls the heritage by having the right as well as the obligation to regulate and take care of the inheritance rights of his brothers or sisters on the basis of deliberation and consensus. Individual inheriting systems tend to be found in parental communities.

According to Rifiki, "in parental society there are rights and obligations that are no different between women and men. Girls have the same inheritance rights as boys to inheritance. The same inheritance rights contain the understanding of the right to be applied equally by their parents in the process of forwarding and passing family property.".

Government directs the inheritance system to the individual inheritance system through the provisions of MPRS, seminars on customary law and national legal development and through judges' rulings that direct the development of customary inheritance law towards the system of individual inheritance. MPRS Decree Number II/MPRS/1960 paragraph 402 letter c sub 4, book I volume III states "all inheritance is for children and widows, meaning that a child both a girl and a boy together with a widow is an heir to her late husband. MPRS Decree Number II/MPRS/1960 requires family law and inheritance law in the direction of parental customary law.”.

In addition to the MPRS Decree, Article 31 of Law No. 1 of 1974 concerning Marriage regulates the balance of rights and positions between wives and husbands in society. The position between women and men is also affirmed by the decisions of judges such as the Supreme Court of the Republic of Indonesia No. 179K / SIP / 1961 dated November 1, 
1961. Through the ruling, the daughter is an heir who has the right to receive inheritance from the heirs.

In 1975, a Seminar on Customary Law and National Legal Development was held in Yogyakarta city with the results of formulations on the decision on customary law in jurisprudence reminding that the growth of Indonesian society in its development towards the direction of degrees equality both on the part of women and men and the recognition of girls is a necessary heir as applicable in the parental inheritance system..

Basis of the same legal consideration can be found based on the Supreme Court's Decision in the dispute of inheritance cases in the customary law of the Batak Mandailing People who hold the patrilineal kinship system. Through The Decree No. 415 K / SIP / 1970 dated June 16, 1971 in the case of Usman et al against Marah Iman Nasution et al stated "customary law in Tapanuli has now developed towards granting equal rights to girls and boys."

The supreme court's ruling regarding the equal rights of both men and women is consistently enforced in the next supreme court ruling, namely Decision No. 1048K / Pdt / 2012 dated September 26, 2012. In this case related to the division of the customary heirs Rote Ndao East Nusa Tenggara. The ruling was further incorporated into one of the important rulings (landmark decision) of the Supreme Court in the 2012 Annual Report stating "the reasons for cassation can be justified, Judex Facti or The Kupang High Court which overturned the decision of the District Court of Rote Ndao which incorrectly applied the law with consideration on the basis of Article 17 of the Human Rights Law and Jurisprudence of the Supreme Court of Indonesia Number 179K / SIP / 1961 dated November 11, 1961 which states that the rights of women's inheritance are equated with those of the Supreme Court of Indonesia No. 179K /SIP/1961 dated November 11, 1961 which states that the rights of women's inheritance are equated with those of the Supreme Court of Indonesia No. 179K/SIP/1961 dated November 11, 1961, stating that women's inheritance rights are equated with those of the Supreme Court of Indonesia No. 179K/SIP/1961 dated November 11, 1961, stating that women's inheritance rights are equated with men's of the Supreme Court of Indonesia No. 179K/SIP/1961 dated November 11, 1961. That is, customary laws that are not in accordance with the development of law in society, such as customary law that does not recognize women's rights equal to the position of men can no longer be maintained"

The same decision was further decided by the Supreme Court on June 19, 2017 in Decision No. 573K/Pdt/2017 related to the division of heirs in the Batak Indigenous Peoples and Decision No. 1130K/Pdt/2017 dated July 10, 2017 related to the division of inheritance in the Manggarai customs of East Nusa Tenggara. The legal view in favor of gender equality and justice as stated in the above rulings is further strengthened by the MA through regulatory functions or legislation with the Enactment of MA Regulation No. 3 of 2017 concerning Guidelines for Adjudicating Women's Cases Against the Law on August 4, 2017. Since 1961 in inheritance law there has been consistency. The attitude imposed by the SUPREME Court in terms of equal rights both those of men and women, then the legal attitude has become jurisprudence for the MA. 


\section{Conclusion}

Based on the discussions that have been submitted, it can be concluded that the first practice of sharing inheritance to the heirs of girls according to the patrilineal kinship system has undergone changes. There are several reasons that can affect the development that brings change for indigenous peoples, namely the economy of education level, displacement (migration), and understanding of religion and social and Court decision. The existence of the judge's decision that is used as a handle and becomes jurisprudence as contained in the Circular Letter MA, which states to share the inheritance to girls and boys should be treated equally. In the application in indigenous peoples in the patrilineal system that is embraced and must be applied, the degree of boys and girls is the equal position.

Both the development of customary inheritance law for the heirs of girls according to the patrilineal kinship system began since the expiration of Supreme Court Decision No.179K/Sip/1961 and has led to a patrilineal system that gives the royality towards equality of position between rights for boys and rights for girls influenced by several factors such as humanity, justice and equality for boys and girls. It is a more neutral system and gives more respect to women. Thus with this neutral nature, there has been modernization that has a direction to homogeneity, i.e. the existence of equality of position both against men and women, who have also provided protection for the girls position in customary law in their families.

\section{References}

Ali, Metode Penelitian Hukum, Sinar Grafika, Jakarta

Bambang Daru Nugroho, Hukum Adat, PT.Refika Aditama, Bandung, 2015

Bushar Muhammad, Pokok-pokok Hukum Adat, Pradnya Paramita, Jakarta, 2000

Dewi, Wulansari, Hukum Adat Indonesia Suatu Pengantar, Refika Aditama, Bandung: 2010

Eman Suparman, Hukum Waris Indonesia, Refika Aditama, Bandung, 2005

Hilman Hadikusuma, Hukum Waris Adat, Citra Aditya Bakti, Bandung, 2003

Hilman Hadikusuma, Hukum Waris Adat, Citra Aditya Bakti, Bandung, 2003

Hilman Hadikusuma, Pengantar Ilmu Hukum Adat Indonesia, Mandar Maju, Bandung, 2014

I.G.N. Sugangga, Hukum Waris Adat, UNDIP, Semarang: 1995

Nalle, V. I. W.. Universitas Katolik Darma Cendika. Universitas Katolik Darma Cendika, (Pembaharuan Hukum Waris Adat Dalam Putusan Pengadilan). 2017, di unduh dari https://webcache.googleusercontent.com/search?q=cache:wAQ3WucQpsUJ:https://jur nal.ugm.ac.id/jmh/article/download/37201/22792+\&cd=2\&hl=en\&ct=clnk\&gl=id

Nasution, Metode Penelitian Ilmu Hukum, CV. Mandar Maju, Bandung, 2010

Nico Ngani, Perkembangan Hukum Adat Indonesia, Pustaka Yustisia, Yogyakarta, 2012

Peraturan Mahkamah Agung Nomor 3 Tahun 2017 Tentang Pedoman Mengadili Perkara Perempuan Berhadapan Dengan Hukum

Peter Mahmud Marzuki, Penelitian Hukum, Kencana Prenada Media Group, Jakarta: 2007

Prodjojo Hamidjojo, Hukum Waris Indonesia, Stensil, Jakarta, 2000

Putusan Mahkamah Agung Republik Indonesia Nomor 179K/SIP/1961

Putusan Nomor 1130K/Pdt/2017 terkait pembagian waris dalam adat Manggarai Nusa Tenggara Timur

Putusan Nomor 573K/Pdt/2017 terkait pembagian waris dalam adat Batak

Rifiqi, Harta Peninggalan dari Pewaris terhadap Hak Waris Anak Perempuan di Bali, Penegakan Hukum Vol.1 No.1 Juni 2014

Soejono Soekanto, Hukum Adat Indonesia, Raja Grafindo Persada, Jakarta, 2012

Soerjowinoto, Metode Penulisan Karya Hukum Buku Panduan Mahasiswa, Fakultas Hukum, Universitas Katolik Soegijapranata, Semarang: 2014 
Titik Triwulan Tutik, Hukum Perdata dalam Sistem Hukum Nasional. Kencana Preada Media. Jakarta: 2008

Undang- Undang Nomor 39 tahun 1999 Tentang Hak Asasi Manusia

Undang-Undang Dasar NKRI 1945 Pasca Amandemen

Undang-Undang Hukum Perdata.

Undang-Undang Nomor 1 Tahun 1974 Tentang Perkawinan

Zuhraini, Serba Serbi Hukum Adat, Fakultas syariah IAIN Raden Intan, Bandar Lampung, 2016 